\title{
Cyclic 3'-5' Guanosine Monophosphate-dependent Activity in Leishmania amazonensis
}

\author{
LF-Géigel/ ${ }^{+}$, LL Leon* \\ Departamento de Parasitología, Instituto de Medicina Tropical Pedro Kourí, Autopista Novia del Mediodia, Ciudad Habana, \\ Cuba *Departamento de Imunologia, Instituto Oswaldo Cruz-Fiocruz, Rio de Janeiro, RJ, Brasil
}

Although there are some data concerning the nitric oxide and the cyclic 3'-5'guanosine monophosphate (cGMP) signaling pathway in trypanosomatids, there is no report about the cGMP-dependent enzymatic activity identification. In this sense, a cGMP dependent activity was detected on soluble fraction from Leishmania amazonensis promastigotes with a high metacyclic level. This information is valuable in order to explore the metabolic pathway of G kinase protein in this parasite.

Key words: Leishmania amazonensis - cyclic 3'-5'-guanosine monophosphate - metacyclogenesis

Leishmania spp. are evolutionary ancient protozoans that cause a spectrum of diseases ranging from asymptomatic to lethal ones. Despite the fact that 12 million new cases of leishmaniasis occur each year, current options for disease control and treatment are limited (Modabber 1987). A more effective and less toxic treatment, as well as a protective vaccine, is needed to manage these diseases.

In mammalian, protein kinases are a family of enzymes that participate in a wide number of processes as metabolism, gene expression, growth and cell differentiation, but their precise functions are not well defined (Vo et al. 1998). Protein kinases in parasites have been described (Ulloa et al. 1988, Gómez et al. 1989,1999, Farber et al. 1997, Flawiá et al. 1997, Shalaby et al. 2001). In Leishmania evidences indicate that the parasite possesses the capability of regulating the properties and function of, not only its own cell surface macromolecules, but also those of host cells through phosphorylation and desphosphorylation reactions (Glew et al. 1988, Vannier-Santos et al. 2002).

Considering the importance of the signaling pathway between cells and also the fact that little has been described about the phosphorylation activity associated to the cyclic 3'-5' guanosine monophoshate (cGMP) in Leishmania spp. our study was intended to evaluate this enzymatic activity in promastigotes of L. amazonensis.

The enzymatic activity dependent on cGMP was detected in soluble fraction (FS) from L. amazonensis promastigotes (MHOM/BR/77/LTB0016, kindly provided

This work was supported by a grant from Instituto Oswaldo Cruz.

${ }^{+}$Corresponding autor. Fax: +53-7-202.0633. E-mail: lfgeigel@ipk.sld.cu

Received 5 July 2002

Accepted 9 April 2003 by leishmaniasis laboratory of the Instituto Oswaldo Cruz, Rio de Janeiro. The parasites were maintained by continuous passage in $\mathrm{Balb} / \mathrm{c}$ mice. Amastigotes isolated from infected foot were propagated as promastigotes in Schneider's insect medium supplemented with $10 \%$ fetal calf serum. Parasites were routinely sub-cultured every $72 \mathrm{~h}$ and freshly transformed virulent promastigotes were obtained. The FS, supplemented with inhibitor of proteases, was separated by a fast protein liquid chromatography system on MONO Q column (HR 5/5) with a linear gradient of $0-400 \mathrm{mM} \mathrm{NaCl}$ in $25 \mathrm{mM}$ Tris/ $\mathrm{HCl} \mathrm{pH} 7.4$ (Patel \& Diamond 1997). Different peaks were obtained and the enzymatic assay was determined by measuring ${ }^{32} \mathrm{P}$ incorporation from $\left[\gamma_{-}{ }^{32} \mathrm{P}\right]$ ATP as described previously (Wolfe et al. 1989). Activity was detected in a peak eluted with $0.14 \mathrm{M}$ of $\mathrm{NaCl}$ and the activity was higher in the presence of the cyclic nucleotide ( $10 \mu \mathrm{M}$ cGMP). The increase of the activity was statistically significant $(\mathrm{p}=$ 0.0255 ) when compared with the reaction in the absence of cGMP. The activity associated to cGMP was significantly reduced $(p=0.0077)$ in the presence of $10 \mu \mathrm{g} / \mathrm{ml}$ of Arg-Lys-Arg-Ala-Arg-Lys-Glu, a synthetic peptide inhibitor of the cGMP-dependent protein kinase, PKG (Figure). Previous studies have demonstrated that AMP-dependent protein kinase (PKA) and PKG have similar catalytic activities, suggesting that high homology exists among the catalytic domain of these two enzymes (Yan et al. 1996). In this work $200 \mu \mathrm{g} / \mathrm{ml}$ of an specific PKA inhibitor, PKAI (TTYADFIAS GRTGRRNAIHD) was added to the reaction mixture, to eliminate any contribution from its activity to the kinase activity investigated.

As far as we know, this is the first report about the cGMP dependent activity in Leishmania spp. but the biological significance of the above mentioned data remains to be defined. New knowledge about enzymes, proteins and other macromolecules that are part of important metabolic ways for the parasite could supply information about their function and the role in the life cycle or in the infectivity of the protozoa. 


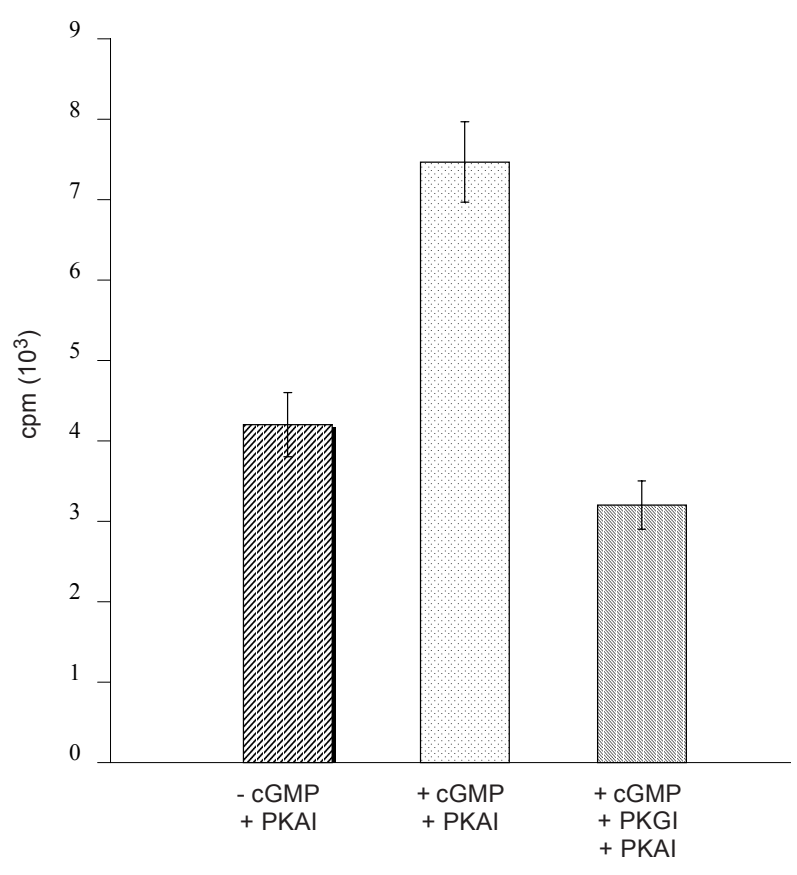

Cyclic 3'-5'-guanosine monophosphate (cGMP)-dependent enzymatic activity of the peak obtained with the linear gradient by ion exchange chromatography. The enzymatic activity was measured in absence $(\mathbb{Y} \mathbb{P} \mathbb{Y})$ and in the presence $(\square)$ of cGMP. A synthetic peptide inhibitor of the protein kinase (PKG) (PKGI, was also evaluated. In all experiments a PKAI was included. Results shown here represent a means of three experiments.

\section{ACKNOWLEDGMENTS}

To MSc Ana Cristina Pereira Duarte, Chemistry School, Federal University of Rio de Janeiro, for technical support. To Dr Gustavo López, Physic Institute, Federal University of Rio de Janeiro for encouragement.

\section{REFERENCES}

Farber PM, Graeser R, Franklin R, Kappes B 1997. Molecular cloning and characterization of a second calcium-dependent protein kinase of Plasmodium falciparum. Mol Biochem Parasitol 87: 283-292.

Flawiá MM, Téllez-Iñón MT, Torres HN 1997. Signal transduction mechanisms in Trypanosoma cruzi. Parasitol Today 13: 30-33.

Glew RH, Saha AK, Das S, Remaley AT 1988. Biochemistry of the Leishmania species. Microbiol Rev 52: 412-432.

Gómez ML, Erijman L, Arauzo S, Torres HN, Téllez-Iñón MT 1989. Protein kinase C in Trypanosoma cruzi epimastigote forms: partial purification and characterization. Mol Biochem Parasitol 36: 101-108.

Gómez ML, Ochatt CM, Kazanietz MG, Torres HN, TéllezIñón MT 1999. Biochemical and imunological studies of protein kinase C from Trypanosoma cruzi. Int J Parasitol 29: 981-989.

Modabber F 1987. The leishmaniases. In, J Maurice, AM Pearce (eds), Tropical Disease Research, a Global Portnership, Eighth Programme Report, TDR, World Health Organization, Geneva, p. 99-112.

Patel AI, Diamond J 1997. Activation of guanosine 3',5'-cyclic monophosphate (cGMP)-dependent protein kinase in rabbit aorta by nitroglycerin and sodium nitroprusside. $J$ Pharmacol Exp Therapeutics 283: 885-895.

Shalaby T, Liniger M, Seebeck T 2001 The regulatory subunit of a cGMP-regulated protein kinase A of Trypanosoma brucei. Eur J Biochem 268: 6197-6206.

Ulloa RM, Mesri E, Esteva M, Torres HN, Tellez-Iñón MT 1988. Cyclic AMP-dependent protein kinase activity in Trypanosoma cruzi. Biochem J 255: 319-326.

Vannier-Santos MA, Martiny A, de Souza W 2002. Cell biology of Leishmania spp.: invading and evading. Curr Pharm Des 8: 297-318.

Vo NK, Gettemy JM, Coghlan VM 1998. Identification of cGMP-dependent protein kinase anchoring proteins (GKAPs). Biochem Biophys Res Commun 246: 831-835.

Yan X, Corbin JD, Francis SH, Lawrence DS 1996. Precision targeting of protein kinases. J Biol Chem 271: 1845-1848.

Wolfe L, Corbin JD, Francis SH 1989 Characterization of a novel isoenzyme of cGMP-dependent protein kinase from bovine aorta. J Biol Chem 264: 7734-7741. 